\title{
Occupancy modeling of Parnassius clodius butterfly populations in Grand Teton National Park, Wyoming
}

\author{
Kimberly E. Szcodronski ${ }^{1,2}$ (D) Diane M. Debinski ${ }^{1,3} \cdot$ Robert W. Klaver $^{4}$
}

Received: 17 August 2017 / Accepted: 20 April 2018 / Published online: 3 May 2018

(c) The Author(s) 2018

\begin{abstract}
Estimating occupancy patterns and identifying vegetation characteristics that influence the presence of butterfly species are essential approaches needed for determining how habitat changes may affect butterfly populations in the future. The montane butterfly species, Parnassius clodius, was investigated to identify patterns of occupancy relating to habitat variables in Grand Teton National Park and Bridger-Teton National Forest, Wyoming, United States. A series of presence-absence surveys were conducted in 2013 in 41 mesic to xeric montane meadows that were considered suitable habitat for $P$. clodius during their flight season (June-July) to estimate occupancy $(\psi)$ and detection probability $(p)$. According to the null constant parameter model, $P$. clodius had high occupancy of $\psi=0.78 \pm 0.07 \mathrm{SE}$ and detection probability of $p=0.75 \pm 0.04 \mathrm{SE}$. In models testing covariates, the most important habitat indicator for the occupancy of $P$. clodius was a strong negative association with big sagebrush (Artemisia tridentata; $\beta=-21.39 \pm 21.10 \mathrm{SE}$ ) and lupine (Lupinus spp.; $\beta=-20.03 \pm 21.24 \mathrm{SE}$ ). While $P$. clodius was found at a high proportion of meadows surveyed, the presence of $A$. tridentata may limit their distribution within montane meadows at a landscape scale because A. tridentata dominates a large percentage of the montane meadows in our study area. Future climate scenarios predicted for high elevations globally could cause habitat shifts and put populations of P. clodius and similar non-migratory butterfly populations at risk.
\end{abstract}

Keywords Parnassius clodius · Occupancy modeling · Butterflies · Grand Teton National Park · Lepidoptera · Montane meadows

Electronic supplementary material The online version of this article (https://doi.org/10.1007/s10841-018-0060-1) contains supplementary material, which is available to authorized users.

Diane M. Debinski

diane.debinski@montana.edu

1 Department of Ecology, Evolution, and Organismal Biology, Iowa State University, 251 Bessey Hall, Ames, IA 50011, USA

2 Present Address: U.S. Geological Survey, Northern Rocky Mountain Science Center, 2327 University Way, Suite 2, Bozeman, MT 59715, USA

3 Present Address: Department of Ecology, Montana State University, 310 Lewis Hall, Bozeman, MT 59717, USA

4 U.S. Geological Survey, Iowa Cooperative Fish and Wildlife Research Unit, Department of Natural Resource Ecology and Management, Iowa State University, 342 Science II, Ames, IA 50011, USA

\section{Introduction}

Non-migratory butterfly species endemic to montane meadows are particularly susceptible to the effects of habitat loss and climate change because they are: (1) dependent upon specialized plant-insect interactions that are at risk of phenological mismatching (Parmesan 2007; Singer and Parmesan 2010), (2) constrained to potentially shrinking habitats due to forest encroachment (Roland et al. 2000; Matter et al. 2004; Roland and Matter 2007), and (3) vulnerable to genetic isolation as a result of small, isolated populations (Keyghobadi et al. 1999, 2005). Climate scenarios predict that high elevations where montane meadow butterfly populations exist will face larger, more rapid changes and are likely to have the greatest rate of species loss compared to other ecosystems (Kim et al. 2002; Thuiller et al. 2005). Due to the combined and potentially synergistic threats of habitat loss and climate change threatening butterflies worldwide (Warren et al. 2001; McLaughlin et al. 2002; Forister et al. 2010), it is essential to determine occupancy and identify 
habitat requirements for sensitive montane meadow butterfly species in order to prioritize conservation efforts.

Our study focused on the Clodius Parnassian butterfly (Parnassius clodius; Lepidoptera: Papilionidae) in Grand Teton National Park (GRTE) and the surrounding BridgerTeton National Forest (BTNF) and John D. Rockefeller, Jr. Memorial Parkway (JODR) in the Rocky Mountains of Wyoming, United States (hereafter Teton region). This species is a range-restricted, high elevation montane meadow butterfly species for which habitat alterations and climate change may cause increasing conservation concerns. Although $P$. clodius is not currently threatened, it faces similar issues to those of the related European Apollo butterfly (Parnassius apollo), which has been declining throughout the twentieth century due to long-term climatic changes, habitat succession, anthropogenic factors, genetic erosion, and behavioral changes in small demes (Nakonieczny et al. 2007). P. apollo is categorized by the International Union for the Conservation of Nature as Near Threatened (van Swaay et al. 2011) and is considered a high priority for conservation (Todisco et al. 2010). Parnassius species, known as the "invertebrate epitome of the conservation of mountain habitats" in Europe, are considered a valuable study organism and can serve as a flagship species for montane environments (Todisco et al. 2010). By studying the habitat preferences of $P$. clodius, we may be able to anticipate similar threats $P$. apollo faces and predict how these threats may impact $P$. clodius in the future.

Prior to this research, there was limited information on the distribution and abundance of Parnassius populations in the Teton region outside of one well-studied population of $P$. clodius in the meadow along Pilgrim Creek road $(1500 \times 300 \mathrm{~m}$ in size) within GRTE (Auckland et al. 2004). Mark-recapture studies were conducted on the Pilgrim Creek population, considered to be one of the largest populations of $P$. clodius in the Teton region, to assess population parameters including sex ratio, population size, percentage of mated females, and emergence dates for males and females (Auckland et al. 2004). Population fluctuations documented by these mark-recapture studies from 1998 to 2000 (Auckland et al. 2004) and 2009-2012 (Jill A. Sherwood and Diane M. Debinski, unpublished data) indicated the need for a better understanding of the ecosystem-wide distribution pattern of $P$. clodius. Given there are no extensive data on $P$. clodius outside of Pilgrim Creek, it is unclear whether the current population configuration across the Teton region is a stable one.

To document site occupancy patterns of $P$. clodius on an ecosystem-wide level and to assess how particular components of habitat influenced patterns of occupancy, we conducted a series of presence-absence butterfly surveys and vegetation surveys in potentially suitable habitat for $P$. clodius in the Teton region in 2012 and 2013. There were two objectives of this study: (1) use occupancy estimates and detection probabilities of $P$. clodius to determine where current populations exist in the Teton region and (2) analyze potentially suitable Parnassius butterfly habitat to examine fine-scale habitat preferences of $P$. clodius. For the second objective, we hypothesized that the occupancy of $P$. clodius would be positively correlated with abundance of low sagebrush (Artemisia arbuscula) and their preferred nectar source, sulphur flower buckwheat (Eriogonum umbellatum). Field observations indicated that $A$. arbuscula is generally associated with a higher cover of bare ground, which allows for the growth of their host plant, longhorn steershead (Dicentra uniflora), and important nectaring forbs.

\section{Methods}

\section{Species description}

Parnassius clodius is a medium-sized white butterfly that inhabits montane meadows. The species occurs along the northern Rocky Mountains in northwestern United States and western Canada (Scott 1986). Parnassius species are univoltine butterflies that overwinter as eggs, pupate on the soil during spring, and have an adult flight season from mid June to mid July (Scott 1986). The host plant of $P$. clodius is $D$. uniflora, a spring ephemeral wildflower. The primary nectar source of $P$. clodius in the Teton region is E. umbellatum (Auckland et al. 2004). Data collected during 2011-2013 documented that several additional nectar sources are being used by $P$. clodius in the Teton region, including arrowleaved balsamroot (Balsamorhiza sagittata), groundsel (Senecio spp.), sticky geranium (Geranium viscosissimum), nettle-leaved giant-hyssop (Agastache urticifolia), spreading dogbane (Apocynum androsaemifolium), several yellow and purple flowering species within the Asteraceae family, snowbrush ceanothus (Ceanothus velutinus), birch-leaved spiraea (Spiraea betulifolia), and common snowberry (Symphoricarpos albus; Kimberly E. Szcodronski and Jill A. Sherwood, unpublished data).

\section{Study area}

The Teton region is a relatively pristine, large-scale protected area within the Greater Yellowstone Ecosystem (GYE) that contains a heterogeneous distribution of habitat types along elevation and hydrological gradients that include conifer and aspen forest (Populus spp.), willow shrubland (Salix spp.), sagebrush flats (Artemisia spp.), and montane meadows. Landsat satellite multispectral imagery data were used to classify six montane meadow types in the GYE along a hydrological gradient ranging from hydric willow and sedge (Carex spp.) meadows to mesic meadows with high forb 
cover to xeric sagebrush meadows (Jakubauskas et al. 1996, 1998; Kindscher et al. 1998; Debinski et al. 1999). From 1997 to 2007, Debinski et al. $(2006,2010,2013)$ collected vegetation and butterfly distribution data across this hydrological gradient within 55 montane meadows in the GYE, including 25 meadows in the Teton region. Butterfly abundance counts from these surveys indicated that Parnassius butterflies were most often found in mesic and xeric meadows (Debinski et al. 2013). Furthermore, Auckland et al. (2004) determined P. clodius was located at highest densities in the Teton region in "dry, cobbly, sagebrush meadows where its host plant species, D. uniflora, is abundant."

Based on the butterfly's known habitat preferences, study sites for this project were restricted to meadows with montane mesic herbaceous vegetation, montane xeric herbaceous vegetation, and Artemisia spp. cover including big sagebrush (Artemisia tridentata) and A. arbuscula. The 2002-2005 GRTE Vegetation Mapping Project (Cogan et al. 2005) provided geospatial vegetation data that were used in ArcGIS 10.3.1 (ESRI 2015) to identify 61 meadows as potentially suitable Parnassius habitat in the Teton region. Of the 61 sites, 41 sites were surveyed as part of the study in 2013, three sites were not classified as potential habitat when ground-truthed and were removed from the study, nine sites were excluded due to inaccessibility $(>4.5 \mathrm{~km}$ from an access road), and the flight season ended before we were able to survey the remaining eight sites. Nineteen of the 41 sites were also surveyed in 2012 during a pilot study. The selected study sites were distributed across $\sim 135,072$ ha (Supplemental Material, Table A.1; Table A.2). Study sites ranged in size from 1 to 1307 ha and in elevation from 2006-2491 m (Supplemental Material, Table A.1; Table A.2).

\section{Butterfly surveys}

Presence-absence butterfly surveys were conducted for $P$. clodius in 19 study sites in the summer of 2012 (Supplemental Material, Table A.1) and 41 study sites (including all of the 2012 sites) during the summer of 2013 (Supplemental Material, Table A.2). In our analysis "presence" is defined as occupancy and "absence" is defined as both true absence and non-detection. While the 2012 surveys were not included in all components of our final analyses, these data are useful in providing evidence that the results of our 2013 surveys were representative of occupancy patterns across years. Surveys occurred from mid June to late July. Based on delayed vegetation phenology and later butterfly emergence in higher elevation sites, we suspected that $P$. clodius would emerge at higher elevation sites 1-2 weeks later than lower elevation sites. Therefore, we conducted surveys at lower elevation sites first and moved up along the elevation gradient as the season progressed. The emergence date of $P$. clodius varies annually; therefore it was important to verify that the species had emerged before surveys began. The Pilgrim Creek population, one of the largest $P$. clodius populations in the Teton region and among the lower elevation sites, was monitored frequently near the predicted Parnassius adult flight season to document butterfly emergence and determine the start of the survey period.

To account for imperfect detection, presence-absence surveys were conducted at study sites in 2012 and 2013 throughout $P$. clodius' flight season by two independent observers per visit (MacKenzie et al. 2002, 2006; MacKenzie and Royle 2005). Each survey by an observer was considered an independent detection occasion. In 2012, we surveyed 19 sites with six sites visited twice (four detection occasions/site) and 13 sites visited once (two detection occasions/site). In 2013, we surveyed 41 sites with 39 sites visited twice (four detection occasions/site), one site visited twice with three detection occasions (one visit with one surveyor and one visit with two surveyors), and one site surveyed once by one observer (one detection occasion). The detection pattern obtained across multiple visits within a relatively short time was used to estimate detection probability and to correct for false absences (MacKenzie et al. 2002, 2006). Each observer searched for $P$. clodius for $30 \mathrm{~min}$ per survey. The total number of $P$. clodius observed at a site was summed across observers and surveys at each location for 2013. A site was considered occupied if at least one $P$. clodius was verified to be present in the meadow in at least one of the surveys within a year. Detection may have been lower in larger meadows ( $>250$ ha) due to their size, but additional site visits outside of our surveys support our findings of no occupancy.

The other Parnassius species in the Teton region, Rocky Mountain Parnassian (Parnassius smintheus), has similar wing coloration of $P$. clodius and is present in low numbers in xeric meadows throughout the region (Debinski et al. 2013). Due to the high similarity in phenotype, each Parnassius butterfly observed was caught with an insect net during surveys to verify species identity and was released unharmed at the end of the survey period. Based on high $P$. clodius recapture rates $(\overline{\mathrm{x}}=26 \%)$ from Pilgrim Creek mark-recapture studies from 1998 to 2000 (Auckland et al. 2004) and 2009-2012 (Jill A. Sherwood and Diane M. Debinski, unpublished data), careful handling by trained technicians does not have a negative effect on the survival of this species. Butterfly surveys were performed during optimal butterfly flight conditions which occurred mid June-late July between 10:00 and 17:00 $\mathrm{h}$ when the temperature was above $21^{\circ} \mathrm{C}$, sun was not obscured by clouds, and wind speed was $<16 \mathrm{~km} / \mathrm{h}$ (Auckland et al. 2004). 


\section{Vegetation surveys}

We surveyed vegetation at each study site once during the Parnassius butterfly flight season in the summer of 2013, ranging from mid June-late July depending on the elevation of the study site. Study sites varied considerably in size and were therefore classified into three size classes, with the number of vegetation transects proportional to meadow size ( $<10$ ha = 1 transect, $10-100$ ha $=2$ transects, $>100$ ha=3 transects). Observations indicate vegetation composition is relatively homogenous within vegetation classifications in our study area, which allowed a small sampled area to be representative of an entire meadow. Vegetation data were collected using frequency of occurrence sampling methods (Bonham 2013). We recorded the presence or absence of vegetation categories along a $100 \mathrm{~m}$ transect in $1 \times 0.5 \mathrm{~m}$ quadrat placed every $5 \mathrm{~m}(\mathrm{n}=20$ quadrats per transect). Frequency of occurrence was calculated as the total number of times a vegetation category occurred in a transect divided by the total number of quadrats surveyed. If multiple transects were collected in a meadow, frequency of occurrence was calculated by averaging across transects. Data were recorded for 47 vegetation categories in the field and were condensed into 14 major vegetation categories based on taxonomic similarities and relevance to $P$. clodius to simplify model selection and inference (Supplemental Material, Table A.3). Summary statistics for the major vegetation categories were performed in program $\mathrm{R}$ version 3.4.0 ( $\mathrm{R}$ Core Team 2017) using the lsmeans package (Lenth 2013) to compare sites with $P$. clodius present and absent.

Based on the differences in mean frequency of occurrence between sites with and without $P$. clodius, we further reduced the 14 vegetation categories to seven site covariates to be used in occupancy modeling. The seven covariates included the two dominant sagebrush species, (1) A. tridentata and (2) A. arbuscula as well as (3) dominant forb, Lupinus spp., (4) dominant forb and nectar source, B. sagittata, (5) P. clodius' main nectaring source, E. umbellatum, (6) $P$. smintheus' host plant, Sedum spp., and (7) secondary nectar sources, which encompassed all nectar sources utilized less frequently by $P$. clodius (refer to Supplemental Material, Table A.3 for list of nectar sources). It is important to note that a key habitat variable, the host plant of $P$. clodius, $D$. uniflora, was not included as a covariate due to sampling logistical constraints. D. uniflora is briefly visible in early spring after snowmelt and senesces before the butterfly flight season. We included the host plant of $P$. smintheus, Sedum spp., within the selected covariates to check for any possible association between Sedum spp. and P. clodius. Pearson's product-moment correlation coefficients $(r)$ were calculated in program $\mathrm{R}$ for the seven site covariates using the "cor" function and the "cor.test" function was used to test for significance of the correlations $(p<0.05)$. We did not include any combination of covariates in the same model with $|r|>0.70$.

\section{Occupancy modeling analyses}

We used program PRESENCE version 11.8 (Hines 2006) to analyze occupancy patterns for $P$. clodius by estimating detection probabilities $(p)$ and the probability of a site being occupied $(\psi)$. Single-species, single-season models (MacKenzie et al. 2002, 2006) were used for the analyses. To examine sampling and site covariate effects on detection probability and occupancy, a priori models were developed and evaluated using an information-theoretic approach (Burnham and Anderson 2002).

In order to quantify the consistency in $P$. clodius occupancy patterns across years, we tested occupancy models for a year effect with the combined 2012-2013 data. The model that allowed occupancy to vary by year $[\psi($ year $)$, $p()$.$] had a \Delta \mathrm{AIC}_{c}$ value of 2.01 compared to the top model that kept occupancy constant across years $[\psi(),. p()$.$] . Fur-$ thermore, the beta coefficient for year in the logistic model overlapped one $(\beta=1.13,95 \%$ CI $0.71-1.54)$, indicating a non-informative parameter (Arnold 2010). While the 2012 data were essential for addressing between-year variation in occupancy and detection probabilities, the data from 2012 were insufficient for further occupancy analyses in relation to habitat variables and therefore the remainder of this paper focuses on the results of the 2013 surveys.

A two-stage approach was used to analyze occupancy patterns. First, models were compared by evaluating the effects of sampling and site covariates on detection probability while holding occupancy constant (MacKenzie et al. 2002, 2006). Six models were chosen to evaluate effects on detection probability: meadow size $[\psi(),$.$p (meadow size)], eleva-$ tion $[\psi(),$.$p (elevation)], observer [\psi(),$.$p (observer)], survey$ $[\psi(),$.$p (survey)], fully time-varying model where there are$ different detection probabilities for each detection occasion $[\psi(),. p(\mathrm{t})]$, and null constant parameter model where $p$ and $\psi$ are held constant as a comparison $[\psi(),. p()$.$] . We$ were careful to control for weather conditions during butterfly surveys; therefore factors of wind speed, temperature, and time of day were excluded from model comparisons. Akaike's Information Criterion with small sample bias correction $\left(\mathrm{AIC}_{c}\right)$ and Akaike's weight $\left(w_{\mathrm{i}}\right)$ were used to rank the detection probability models and the best model was selected based on these criteria (Burnham and Anderson 2002). The probability of occupancy given that the species is not detected at a site was calculated by: $[\operatorname{Pr}($ species present and not detected)]/[Pr(species not detected)] (MacKenzie et al. 2006).

Next, 27 additive covariate models were created to evaluate the influence of the seven site covariates on occupancy probability. We followed the recommendations of 
MacKenzie et al. $(2002,2006)$ by using the estimated detection probability value to correct for false absences and estimate occupancy as a function of detection probability. Thus, for each occupancy model, the best-supported detection model was used to account for detection probability in all of the occupancy models. We interpreted the top-supported occupancy models $\left(\Delta \mathrm{AIC}_{c} \leq 2\right.$; Burnham and Anderson 2002) with vegetation variables as covariates as the most important factors influencing the habitat suitability of $P$. clodius. Model-averaged parameter estimates were used to plot the relationship of $P$. clodius with A. tridentata using the RMark package (Laake 2013) in program R.

\section{Results}

P. clodius was present at $12(63 \%)$ out of 19 sites surveyed in 2012 (Supplemental Material, Table A.1; Table A.4) and 32 (78\%) of the 41 sites surveyed in 2013 (Fig. 1; Supplemental Material, Table A.2). Of the sites surveyed, P. clodius was found across the entire elevation gradient from 2006 to $2491 \mathrm{~m}$ (Supplemental Material, Table A.1; Table A.2). In 2013, 21 populations had low total observations of $P$. clodius during the occupancy surveys, with less than nine individuals summed across the four presence-absence surveys $(\overline{\mathrm{x}}=3$ butterflies observed/site; Supplemental Material, Table A.5).
Fig. 1 Vegetation map of Grand Teton National Park, WY and surrounding territories displaying occupancy of Parnassius clodius in meadow sites $(\mathrm{n}=41)$ surveyed from mid June-late July 2013. Sites were considered occupied if at least one butterfly was verified to be present in at least one of the presence-absence butterfly surveys; sites were considered to be unoccupied if no butterflies were observed across all presence-absence surveys

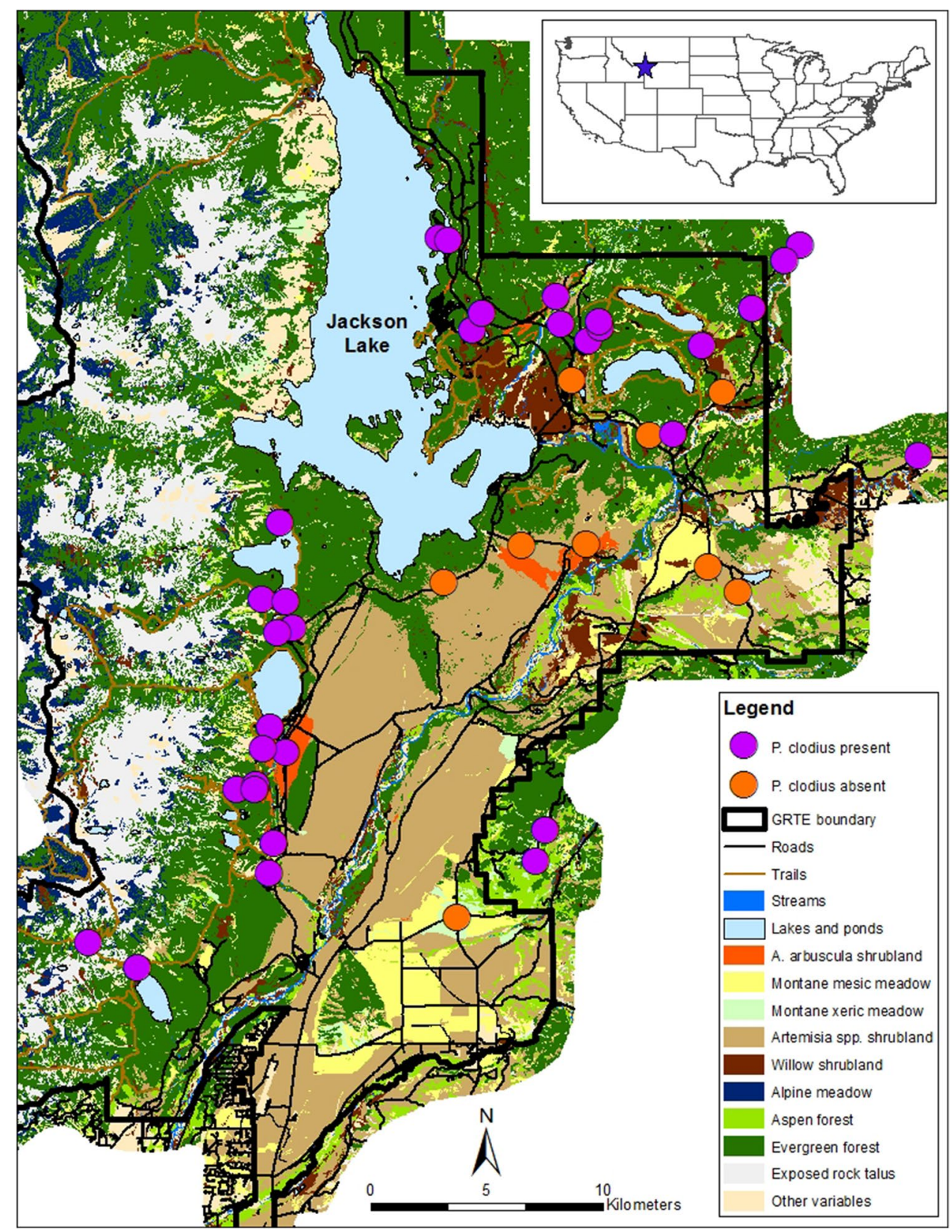


The remaining 11 populations had total observations ranging from 14 to 35 individuals across the presence-absence

Table 1 Summary of model selection statistics examining variables associated with probability of detection $(p)$ of Parnassius clodius in Grand Teton National Park and Bridger-Teton National Forest, WY from mid June-late July 2013

\begin{tabular}{llllll}
\hline Model & $\mathrm{AIC}_{c}$ & $\Delta \mathrm{AIC}_{c}$ & $w_{\mathrm{i}}$ & $\mathrm{K}$ & -21 \\
\hline$\psi(),$.$p (meadow size)$ & 181.67 & 0.00 & 0.513 & 3 & 175.67 \\
$\psi(),$.$p (elevation)$ & 183.91 & 2.24 & 0.167 & 3 & 177.91 \\
$\psi(),. p()$. & 184.07 & 2.40 & 0.154 & 2 & 180.07 \\
$\psi(),$.$p (survey)$ & 185.36 & 3.69 & 0.081 & 3 & 179.36 \\
$\psi(),$.$p (observer)$ & 186.06 & 4.39 & 0.057 & 3 & 180.06 \\
$\psi(),. p(\mathrm{t})$ & 187.53 & 5.86 & 0.027 & 5 & 177.53 \\
\hline
\end{tabular}

Reported is $\mathrm{AIC}_{c}$ value, relative difference in $\mathrm{AIC}_{c}$ compared to topranked model $\left(\Delta \mathrm{AIC}_{c}\right), \mathrm{AIC}_{c}$ model weight $\left(w_{\mathrm{i}}\right)$, number of parameters in the model $(\mathrm{K})$, and twice the negative log-likelihood $(-21)$ surveys $(\overline{\mathrm{x}}=25$ butterflies observed/site; Supplemental Material, Table A.5).

Based on the null constant parameter model, $P$. clodius had high occupancy in 2013 of $\psi=0.78 \pm 0.07 \mathrm{SE}$ (95\% CI $0.63-0.88$ ) with a detection probability of $p=0.75 \pm 0.04 \mathrm{SE}$ (95\% CI 0.67-0.82). The top-ranked detection probability model for P. clodius was $[\psi(),$.$p (meadow size)] (Table 1);$ so this model was used for modeling occupancy. Meadow size was a non-informative parameter for the detection of $P$. clodius ( $\beta=0.01 \pm 0.01 \mathrm{SE}$; Arnold 2010). The probability of occupancy given that the species was not detected at a site for $P$. clodius was 0.01 , indicating a low probability of false negatives in our survey data.

Of the 27 occupancy models assessed for $P$. clodius, one model had strong support $\left(\Delta \mathrm{AIC}_{c} \leq 2\right.$, Table 2$)$. The model with the highest level of support showed that $P$. clodius was negatively correlated with the frequency of occurrence of A. tridentata $(\beta=-21.39 \pm 21.10 \mathrm{SE})$ and Lupinus spp. $(\beta=-20.03 \pm 21.24 \mathrm{SE})$. The model with strong support

Table 2 Summary of model selection statistics examining variables associated with the probability of occupancy ( $\psi$ ) of Parnassius clodius in Grand Teton National Park and Bridger-Teton National Forest, WY from mid June - late July 2013

\begin{tabular}{|c|c|c|c|c|c|}
\hline Model & $\mathrm{AIC}_{c}$ & $\Delta \mathrm{AIC}_{c}$ & $w_{\mathrm{i}}$ & K & -21 \\
\hline$\psi($ A. tridentata + Lupinus spp. $), p($ meadow size $)$ & 147.42 & 0 & 0.84 & 5 & 137.42 \\
\hline$\psi($ A. tridentata $), p($ meadow size $)$ & 153.08 & 5.66 & 0.05 & 4 & 145.08 \\
\hline$\psi($ A. tridentata + E. umbellatum $+B$. sagittata $), p($ meadow size $)$ & 154.56 & 7.14 & 0.02 & 6 & 142.56 \\
\hline$\psi($ A. tridentata + A. arbuscula $), p($ meadow size $)$ & 154.73 & 7.31 & 0.02 & 5 & 144.73 \\
\hline$\psi($ A. tridentata + E. umbellatum $), p($ meadow size $)$ & 154.96 & 7.54 & 0.02 & 5 & 144.96 \\
\hline$\psi($ A. tridentata + Sedum spp. $), p($ meadow size $)$ & 155.08 & 7.66 & 0.02 & 5 & 145.08 \\
\hline$\psi($ A. tridentata $+A$. arbuscula $+E$. umbellatum $+B$. sagittata $), p($ meadow size $)$ & 156.52 & 9.10 & 0.01 & 7 & 142.52 \\
\hline$\psi($ A. tridentata + A. arbuscula + Sedum spp. $), p($ meadow size $)$ & 156.53 & 9.11 & 0.01 & 6 & 144.53 \\
\hline$\psi($ A. tridentata $+E$. umbellatum $+B$. sagittata + secondary nectar $), p($ meadow size $)$ & 156.55 & 9.13 & 0.01 & 7 & 142.55 \\
\hline$\psi($ A. arbuscula + Lupinus spp. + Sedum spp. $), p($ meadow size $)$ & 171.50 & 24.08 & 0.00 & 6 & 159.50 \\
\hline$\psi($ Lupinus spp. $), p($ meadow size $)$ & 173.27 & 25.85 & 0.00 & 4 & 165.27 \\
\hline$\psi($ A. arbuscula + Lupinus spp. $), p($ meadow size $)$ & 174.12 & 26.70 & 0.00 & 5 & 164.12 \\
\hline$\psi($ A. arbuscula + E. umbellatum $), p($ meadow size $)$ & 178.24 & 30.82 & 0.00 & 5 & 168.24 \\
\hline$\psi($ A. arbuscula + E. umbellatum $+B$. sagittata + secondary nectar $), p($ meadow size $)$ & 178.33 & 30.91 & 0.00 & 7 & 164.33 \\
\hline$\psi($ A. arbuscula $+E$. umbellatum $+B$. sagittata $), p($ meadow size $)$ & 178.82 & 31.40 & 0.00 & 6 & 166.82 \\
\hline$\psi($ A. arbuscula + Sedum spp. $), p($ meadow size $)$ & 181.42 & 34.00 & 0.00 & 5 & 171.42 \\
\hline$\psi($ E. umbellatum $), p($ meadow size $)$ & 181.45 & 34.03 & 0.00 & 4 & 173.45 \\
\hline$\psi($ A. arbuscula $), p($ meadow size $)$ & 181.56 & 34.14 & 0.00 & 4 & 173.56 \\
\hline$\psi(),. p($ meadow size $)$ & 181.67 & 34.25 & 0.00 & 3 & 175.67 \\
\hline$\psi($ secondary nectar $), p$ (meadow size $)$ & 182.87 & 35.45 & 0.00 & 4 & 174.87 \\
\hline$\psi($ B. sagittata $), p($ meadow size $)$ & 182.96 & 35.54 & 0.00 & 4 & 174.96 \\
\hline$\psi($ E. umbellatum + B. sagittata $), p($ meadow size $)$ & 182.97 & 35.55 & 0.00 & 5 & 172.97 \\
\hline$\psi($ Sedum spp.), $p$ (meadow size $)$ & 183.46 & 36.04 & 0.00 & 4 & 175.46 \\
\hline$\psi($ E. umbellatum + B. sagittata + secondary nectar $), p($ meadow size $)$ & 184.97 & 37.55 & 0.00 & 6 & 172.97 \\
\hline
\end{tabular}

Reported is Akaike's Information Criterion with small sample bias correction ( $\mathrm{AIC}_{c}$ ), relative difference in $\mathrm{AIC}_{c}$ compared to top-ranked model $\left(\Delta \mathrm{AIC}_{c}\right), \mathrm{AIC}_{c}$ model weight $\left(w_{\mathrm{i}}\right)$, number of parameters in the model $(\mathrm{K})$, and twice the negative log-likelihood $(-21)$. All models used the null constant model for modeling detection probability

The global model (all covariates), [ $\psi($ A. tridentata + A. arbuscula + Lupinus spp.), $p$ (meadow size)], and [ $\psi($ A. tridentata + Lupinus spp. + Sedum spp.), $p$ (meadow size)] failed to converge and were therefore excluded from the analysis 
$\left(\Delta \mathrm{AIC}_{c} \leq 2\right)$ accounted for $84 \%$ of the $\mathrm{AIC}_{c}$ model weight out of all models considered (Table 2). The nine models containing $A$. tridentata as a covariate were the top nine ranked models out of the 27 models assessed (Table 2). A. tridentata and Lupinus spp. are the only variables with evidence of difference between sites where $P$. clodius was present and sites where $P$. clodius was absent, both with strong evidence of a difference ( $<<0.0001$; Fig. 2; Supplemental Material, Table A.6). The occurrence of $P$. clodius decreased as the frequency of occurrence of A. tridentata increased (Fig. 3).

Correlation coefficients for the seven site covariates are provided in the Supplemental Material, Table A.7. Interestingly, there was no significant negative correlation between the two sagebrush species, A. tridentata and A. arbuscula $(r=-0.28, \mathrm{p}=0.08)$. A. arbuscula showed a significant positive correlation with $E$. umbellatum $(r=0.41, \mathrm{p}=0.01)$ and Sedum spp. $(r=0.48, \mathrm{p}=0.001)$. A. tridentata was significantly positively correlated with Lupinus spp. $(r=0.38$, $\mathrm{p}=0.01$ ).

\section{Discussion}

P. clodius was more broadly distributed across the Teton region than expected based on previous studies in the area (Debinski et al. 2006, 2013), occupying 78\% of the meadows we predicted would be suitable in 2013. These results are encouraging in the context of long-term population viability. However, it is also important to consider the total habitat available to $P$. clodius in the Teton region and the population size of $P$. clodius at these meadows. Using the GRTE geospatial vegetation data (Cogan et al. 2005), we calculated the proportion of area within the GRTE and JODR boundary that could serve as suitable habitat for $P$. clodius based on

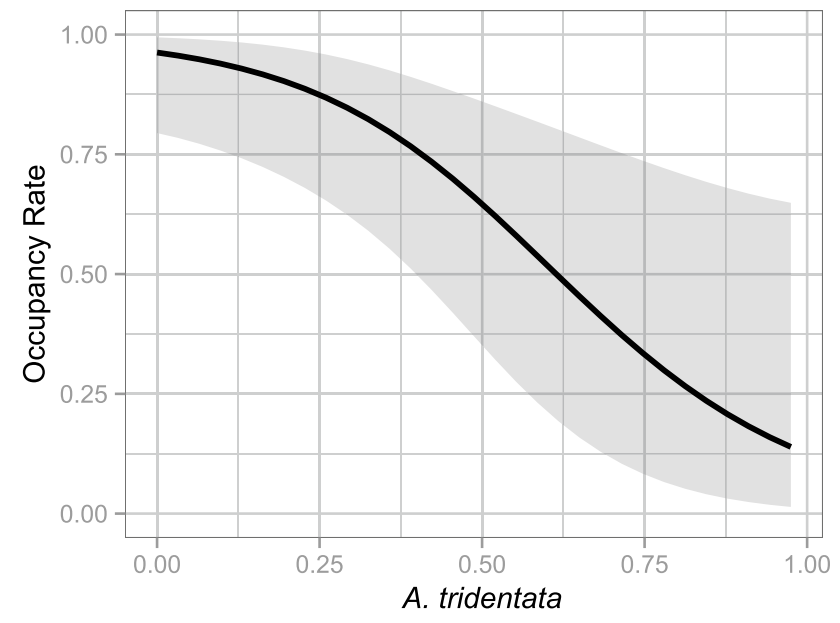

Fig. 3 Influence of the frequency of occurrence of Artemisia tridentata on the probability of Parnassius clodius occupancy in Grand Teton National Park and Bridger-Teton National Forest, WY, during the summer of 2013 . The shaded area depicts the 95\% confidence interval

previous research in the study area (montane mesic herbaceous vegetation, montane xeric herbaceous vegetation, $A$. tridentata shrubland, and $A$. arbuscula shrubland). We found $21.7 \%$ of the study area was made up of these four habitat types. However, the results of this study indicate meadows containing A. tridentata were negatively associated with the presence of $P$. clodius so we removed this habitat type from our calculations. Based on this final classification, 8469 ha (6.3\% of the study area) offers suitable habitat for P. clodius in the Teton region.

Furthermore, 21 out of the 32 locations where P. clodius was found in 2013 had low numbers of individuals observed across the four surveys (Supplemental Material, Table A.5).
Fig. 2 Average frequency of occurrence for vegetation variables in sites where Parnassius clodius was present $(\mathrm{n}=32)$ and sites where Parnassius clodius was absent $(\mathrm{n}=9)$ in Grand Teton National Park and Bridger-Teton National Forest, WY during the summer of 2013. Error bars indicate standard error for each vegetation category and a star above a bar indicates a significant $\mathrm{p}$-value $(\mathrm{p}<0.05)$

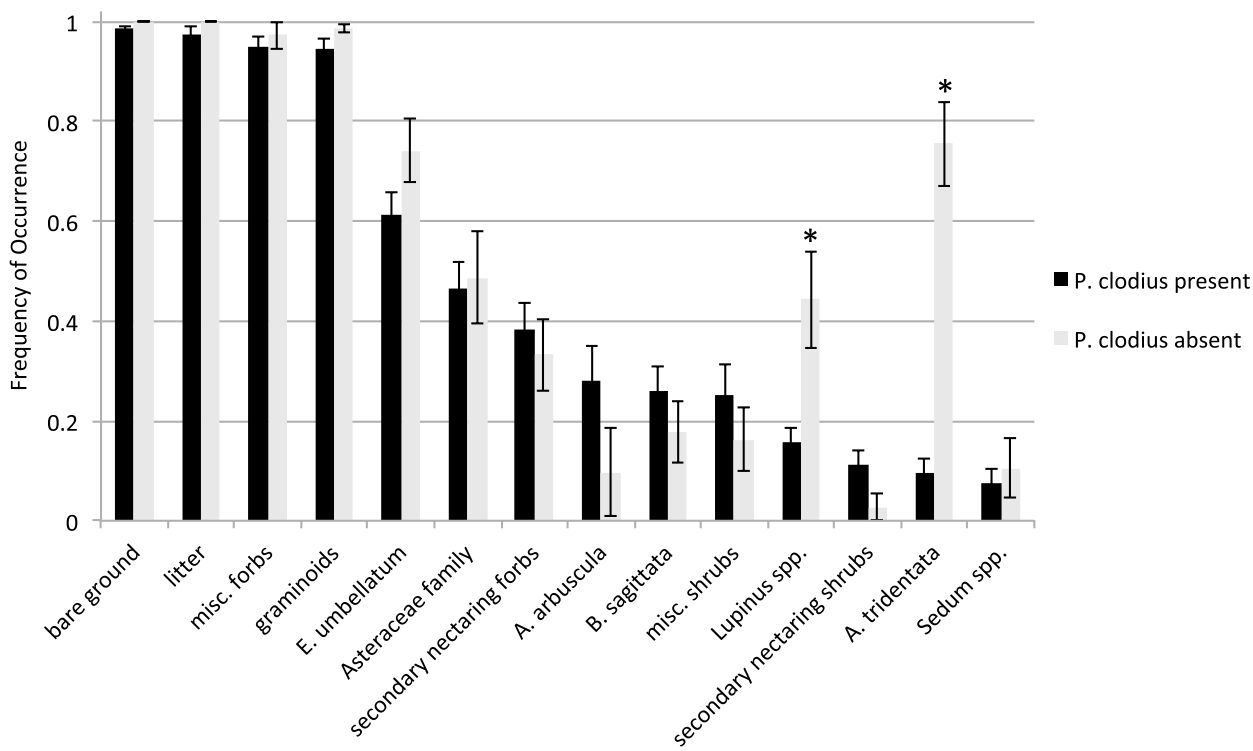


Mark-recapture studies would need to be conducted to obtain estimates of actual population sizes for $P$. clodius, but our data suggest that few populations within this Teton region are large (i.e., maximum number observed $>25$ butterflies summed across all four surveys).

The most supported occupancy model $\left(\mathrm{AIC}_{c}=147.42\right.$, $w_{\mathrm{i}}=0.84$; Burnham and Anderson 2002) in our analysis allowed us to understand factors influencing habitat suitability of $P$. clodius. We expected that the occupancy of $P$. clodius would be positively correlated with the abundance of $A$. arbuscula and their preferred nectar source, E. umbellatum. Our hypothesis was not supported as occupancy modeling results showed no significant relationships with A. arbuscula or E. umbellatum (Table 2). Instead, our analyses indicated that two dominant constituents of montane meadow plant communities, A. tridentata and Lupinus spp., were negatively associated with the presence of $P$. clodius (Table 2). A. tridentata meadows cover a much larger percentage of the habitat (15.4\%) in GRTE and JODR than A. arbuscula $(0.8 \%)$. Even though the negative correlation between the two sagebrush species, A. tridentata and A. arbuscula, was not significant (Supplemental Material, Table A.7), our field observations at a larger spatial scale indicate that meadows with high percent cover of $A$. tridentata often have limited cover of $A$. arbuscula. We speculate that higher percentage of bare ground associated with A. arbuscula is likely to be correlated with $P$. clodius' host plant $D$. uniflora, but this relationship may not have been detected due to the frequency of occurrence sampling methods used to survey vegetation in our study. Notably, we found a significant positive correlation between A. arbuscula and E. umbellatum (Supplemental Material, Table A.7), the two species that we predicted would influence the occupancy of $P$. clodius.

It may be possible that the presence of $A$. tridentata could affect our ability to see $P$. clodius during occupancy surveys, however we do not believe this was an issue in our study area. Although A. tridentata is considerably taller (0.6-1.8 m; Tilley et al. 2012) than A. arbuscula $(0.2-0.4 \mathrm{~m}$; Tilley and St. John 2012), P. clodius is a highly visible butterfly with a flight pattern that is above $A$. tridentata. Additionally, there is ample space between $A$. tridentata shrubs such that observation is not limited in the Teton region. The negative association between $P$. clodius and $A$. tridentata warrants further investigation to determine whether it is a direct relationship or whether $A$. tridentata is negatively associated with other important environmental factors that affect habitat conditions for $P$. clodius. Greater sampling intensity in meadows with high cover of $A$. tridentata could assist in determining whether $A$. tridentata is an indicator of low habitat quality for $P$. clodius or if it reduces detectability.

Our ecosystem-wide surveys have elucidated aspects of population structure that could serve as the foundation for future $P$. clodius metapopulation research in this study area.
The Teton region is a complex landscape in the context of $P$. clodius habitat because the region is characterized by potentially suitable meadows surrounded by unsuitable habitats, including meadows that lack the proper resources for occupancy and conifer forests, which are considered a barrier to movement for Parnassius butterflies (Roland et al. 2000; Matter et al. 2004; Roland and Matter 2007). A metapopulation study would be important to help investigate whether the current metapopulation dynamics are stable and if $P$. clodius is at risk due to potential annual weather variability and climate fluctuations. Colonization and extinction rates would be needed to classify the Teton region in the context of a source-sink or core-satellite metapopulation model. Understanding forest edge responses of $P$. clodius and the connectivity among suitable meadows, as has been done for P. smintheus in Canada (Roland et al. 2000; Matter et al. 2004; Ross et al. 2005), would also aid in assessing the longterm viability of this population.

Our research provides a greater understanding of the distribution of $P$. clodius across the Teton region and valuable insight into habitat characteristics that may be influencing the occupancy of $P$. clodius in montane meadows. P. clodius was found to inhabit a small total number of hectares in the Teton region. This information is useful for managers and scientists in the GYE for monitoring species of concern and predicting the effects of habitat changes on regional plant-insect associations and biodiversity. Furthermore, our research is relevant to conservation efforts for other Parnassius species that are threatened or endangered worldwide, such as P. apollo, because Parnassius species have similar life history patterns and habitat requirements globally. Suitable habitat for butterflies is decreasing in different parts of the world (Warren et al. 2001; Roland and Matter 2007) and butterflies that exist in small, isolated populations scattered across a small portion of the landscape, such as $P$. clodius, could be at a greater risk of decline or extinction than other species. Given the global conservation concerns associated with Parnassius species and the relatively small number of $P$. clodius individuals observed during many of our occupancy surveys, it would be advisable to assess the population trends and explore the metapopulation dynamics of $P$. clodius in this ecosystem to better evaluate conservation concerns for this butterfly in the context of potential future habitat changes.

Acknowledgements Funding for this research was provided by the Center for Global and Regional Environmental Research, University of Wyoming-National Park Service Research Station, and Iowa State University Department of Ecology, Evolution, and Organismal Biology. Grand Teton National Park has provided continual support of our research and has granted research permits necessary to conduct our research. The efforts of the 2002-2005 GRTE Vegetation Mapping Project and geospatial data from K. Mellander made it possible to locate potentially suitable butterfly habitat. We are grateful to the dedication of T. Proescholdt and J. Sherwood in assisting with data 
collection and D. Lewis for assisting with plant identification. We thank W. Clark and T. Grant for statistical consulting and two anonymous reviewers for providing valuable comments on the manuscript. Any mention of trade, product, or firm names is for descriptive purposes only, and does not imply endorsement by the U.S. Government.

Funding This study was funded by University of Wyoming-National Park Service Research Station $(\$ 4,500)$, Center for Global and Regional Environmental Research $(\$ 3,000)$, and Iowa State University Department of Ecology, Evolution, and Organismal Biology $(\$ 2,000)$.

\section{Compliance with ethical standards}

Conflict of interest The authors declare that they have no conflict of interest.

Informed consent Consent to submit to Journal of Insect Conversation has been received explicitly from all co-authors, as well as from the responsible authorities - tacitly or explicitly - at the institute/organization where the work has been carried out.

Research involving human participants and/or animals This research did not involve human participants or animals.

Open Access This article is distributed under the terms of the Creative Commons Attribution 4.0 International License (http://creativeco mmons.org/licenses/by/4.0/), which permits unrestricted use, distribution, and reproduction in any medium, provided you give appropriate credit to the original author(s) and the source, provide a link to the Creative Commons license, and indicate if changes were made.

\section{References}

Arnold TW (2010) Uninformative parameters and model selection using Akaike's information criterion. J Wildl Manag 74(6):1175-1178

Auckland JN, Debinski DM, Clark WR (2004) Survival, movement, and resource use of the butterfly Parnassius clodius. Ecol Entomol 29:139-149

Bonham CD (2013) Measurements for terrestrial vegetation, second edn. Wiley, Oxford

Burnham KP, Anderson DR (2002) Model selection and multimodel inference: a practical information-theoretic approach, second edn. Springer, New York

Cogan D, Varga K, Kittel G, McCloskey K, Abendroth D, Gremer J, Bolen C (2005) 2002-2005 Vegetation Mapping Project. Grand Teton National Park and John D. Rockefeller, Jr. Memorial Parkway Final Project Report. U.S. Department of the Interior, Bureau of Reclamation Technical Memorandum 8260-06-02. Bureau of Reclamation Technical Service Center, Remote Sensing and GIS Group. http://www1.usgs.gov/vip/grte/grterpt.pdf

Debinski DM, Kindscher K, Jakubauskas ME (1999) A remote sensing and GIS-based model of habitats and biodiversity in the Greater Yellowstone Ecosystem. Int J Remote Sens 20(17):3281-3291

Debinski DM, VanNimwegen RE, Jakubauskas ME (2006) Quantifying relationships between bird and butterfly community shifts and environmental change. Ecol Appl 16(1):380-393

Debinski DM, Wickham H, Kindscher K, Caruthers JC, Germino M (2010) Montane meadow change during drought varies with background hydrologic regime and plant functional group. Ecology 91(6):1672-1681
Debinski DM, Caruthers JC, Cook D, Crowley J, Wickham H (2013) Gradient-based habitat affinities predict species vulnerability to drought. Ecology 94(5):1036-1045

ESRI (2015) ArcGIS Desktop: Release 10. Redlands: Environmental Systems Research Institute

Forister ML, McCall AC, Sanders NJ, Fordyce JA, Thorne JH, O'Brien J, Waetjen DP, Shapiro AM (2010) Compounded effects of climate change and habitat alteration shift patterns of butterfly diversity. Proc Natl Acad Sci USA 107(5):2088-2092

Hines JE (2006) PRESENCE-Software to estimate patch occupancy and related parameters. USGS-PWRC. http://www.mbrpwrc.usgs. gov/software/presence.html

Jakubauskas ME, Debinski D, Kindscher K (1996) Integration of multispectral and ecological data for characterizing montane meadow communities in the Greater Yellowstone Ecosystem. Geosci Remote Sens Symposium 4:2300-2302

Jakubauskas M, Kindscher K, Debinski DM (1998) Multitemporal characterization and mapping of montane sagebrush communities using Indian IRS LISS-II imagery. Geocarto Int 13(4):65-74

Keyghobadi N, Roland J, Strobeck C (1999) Influence of landscape on the population genetic structure of the alpine butterfly Parnassius smintheus (Papilionidae). Mol Ecol 8:1481-1495

Keyghobadi N, Roland J, Strobeck C (2005) Genetic differentiation and gene flow among populations of the alpine butterfly, Parnassius smintheus, vary with landscape connectivity. Mol Ecol 14:1897-1909

Kim J, Kim TK, Arritt RW, Miller NL (2002) Impacts of increased atmospheric $\mathrm{CO}_{2}$ on the hydroclimate of the western United States. J Clim 15:1926-1942

Kindscher K, Fraser A, Jakubauskas ME, Debinski DM (1998) Identifying wetland meadows in Grand Teton National Park using remote sensing and average wetland values. Wetl Ecol Manage 5:265-273

Laake JL (2013) RMark: an R interface for analysis of capture-recapture data with MARK. AFSC Processed Rep 2013-01, 25p. Alaska Fish. Sci. Cent., NOAA, Natl. Mar. Fish. Serv., 7600 Sand Point Way NE, Seattle WA 98115

Lenth RV (2013) Lsmeans: least-squares means. R package version 1.06-05. http://www.CRAN.R-project.org/package=lsmeans

MacKenzie DI, Royle JA (2005) Designing occupancy studies: general advice and allocating survey effort. Appl Ecol 42:1105-1114

MacKenzie DI, Nichols JD, Lachman GB, Droege S, Royle JA, Langtimm CA (2002) Estimating site occupancy rates when detection probabilities are less than one. Ecology 83(8):2248-2255

MacKenzie DI, Nichols JD, Royle JA, Pollock KH, Bailey LL, Hines JE (2006) Occupancy estimation and modeling: inferring patterns and dynamics of species occurrence. Elsevier, San Diego

Matter SF, Roland J, Moilanen A, Hanski I (2004) Migration and survival of Parnassius smintheus: detecting effects of habitat for individual butterflies. Ecol Appl 14(5):1526-1534

McLaughlin JF, Hellmann JJ, Boggs CL, Ehrlich PR (2002) Climate change hastens population extinctions. Proc Natl Acad Sci USA 99(9):6070-6074

Nakonieczny M, Kędziorski A, Michalczyk K (2007) Apollo butterfly (Parnassius apollo L.) in Europe-Its history, decline and perspectives of conservation. Funct Ecosyst Communities 1(1):56-79

Parmesan C (2007) Influences of species, latitudes and methodologies on estimates of phenological response to global warming. Glob Change Biol 13:1860-1872

R Core Team (2017) R: A language and environment for statistical computing. R Foundation for Statistical Computing, Vienna

Roland J, Matter SF (2007) Encroaching forests decouple alpine butterfly population dynamics. Proc Natl Acad Sci USA 104(34):13702-13704 
Roland J, Keyghobadi N, Fownes S (2000) Alpine Parnassius butterfly dispersal: effects of landscape and population size. Ecology 81(6):1642-1653

Ross JA, Matter SF, Roland J (2005) Edge avoidance and movement of the butterfly Parnassius smintheus in matrix and non-matrix habitat. Landscape Ecol 20:127-135. https://doi.org/10.1007/ s10980-004-1010-8

Scott JA (1986) The butterflies of North America. Stanford University Press, Stanford

Singer MC, Parmesan C (2010) Phenological asynchrony between herbivorous insects and their hosts: signal of climate change or preexisting adaptive strategy? Philos Trans Royal Soc 365:3161-3176

Thuiller W, Lavorel S, Araújo MB, Sykes MT, Prentice IC (2005) Climate change threats to plant diversity in Europe. Proc Natl Acad Sci USA 102(23):8245-8250

Tilley D, St. John L (2012) Plant guide for low sagebrush (Artemisia arbuscula). USDA-Natural Resources Conservation Service, Aberdeen Plant Materials Center. Aberdeen, Idaho 83210
Tilley DJ, Ogle D, St. John L, Benson B (2012) Plant guide for big sagebrush (Artemisia tridentata). USDA-Natural Resources Conservation Service, Aberdeen Plant Materials Center. Aberdeen, Idaho 83210

Todisco V, Gratton P, Cesaroni D, Sbordoni V (2010) Phylogeography of Parnassius apollo: hints on taxonomy and conservation of a vulnerable glacial butterfly invader. Biol J Lin Soc 101:169-183

van Swaay C, Maes D, Collins S, Munguira ML, Šaŝić M, Settele J, Verovnik R, Warren M, Wiemers M, Wynhoff I, Cuttelod A (2011) Applying IUCN criteria to invertebrates: how red is the red list of European butterflies? Biol Conserv 144:470-478

Warren MS, Hill JK, Thomas JA, Asher J, Fox R, Huntley B, Roy DB, Telfer MG, Jeffcoate S, Harding P, Willis SG, Greatorex-Davies JN, Moss D, Thomas CD (2001) Rapid responses of British butterflies to opposing forces of climate and habitat change. Nature 414:65-69 